\title{
Klęska 1 Brygady Piechoty Rezerwy na Wołyniu w czerwcu 1920 r. w materiałach śledztwa prokuratorskiego
}

\begin{abstract}
Abstrakt: Artykuł przedstawia przyczyny militarne i konsekwencje prawnokarne całkowitej klęski 1 Brygady Piechoty Rezerwy na Wołyniu w czerwcu 1920 r. w czasie ofensywy sowieckiej 1 Armii Konnej i 12 Armii na Wołyniu. Pośpiesznie sformowana 1 BPRez. pod dowództwem płk. Wacława Krupowicza została rozdzielona pomiędzy oddziały Grupy Operacyjnej „Słucz” i dywizje Frontu Ukraińskiego gen. Śmigłego-Rydza. Na polecenie Naczelnego Wodza w sprawie utraty wartości bojowej 1 BPRez. i jej klęski na Wołyniu przeprowadzono śledztwo prokuratorskie w Sądzie Polowym Naczelnego Dowództwa WP w Warszawie. Artykuł uwzględnia wyniki tego śledztwa i przebieg wydarzeń na froncie w świetle zebranych dowodów.
\end{abstract}

Słow a klu c z ow e: wojna, klęska, śledztwo, prokurator wojskowy, odpowiedzialność karna.

Abstract: The article presents the military reasons and criminal-law consequences of the total defeat of the 1st Reserve Infantry Brigade (1st RIBde) in Volhynia in June 1920 during the Soviet offensive of the 1st Cavalry Army and the 12th Army in Volhynia. The hastily formed 1st RIBde under the command of Colonel Wacław Krupowicz was divided between the branches of the "Słucz" Operational Group and the divisions of the General Śmigły-Rydz's Ukrainian Front. On the order of the Commander-in-Chief regarding the loss of combat value of the 1st RIBde and its defeat in Volhynia, a prosecutor's investigation was initiated before the Field Court of the Supreme Command of the Polish Army in Warsaw. The article takes into account the results of this investigation and the course of events on the front in the light of the gathered evidence.

Keyw ords: war, defeat, investigation, military prosecutor, criminal responsibility. 


\section{Organizacja sądownictwa polowego w latach 1919-1921}

Służba sprawiedliwości Wojska Polskiego powstała jako integralna część sił zbrojnych wraz ze wszystkimi agendami i służbami Ministerstwa Spraw Wojskowych (MSWojsk.) i Sztabu Generalnego (SG) WP na przełomie listopada i grudnia 1918 r. Sądy wojskowe były organizowane od końca października 1918 r. w Krakowie, Lublinie, Warszawie i Cieszynie ${ }^{1}$. Kolejne tworzono w końcu listopada 1918 r. w Przemyślu i odblokowanym Lwowie. Natomiast sądy polowe organizowano sukcesywnie przy dowództwach wielkich jednostek w trakcie konfliktu zbrojnego z Ukraińcami o Galicję Wschodnią i w czasie wojny z Rosją sowiecka. Sądownictwo polowe, będące odrębna struktura, powstało wiosna 1919 r. jako integralna część Naczelnego Dowództwa (ND) WP. Do września 1919 r. przy dowództwach wielkich jednostek i związków operacyjnych (dywizji, brygad, grup operacyjnych, armii i frontów) zostały utworzone sądy polowe i referaty sądowo-prawne. Kolejny etap rozwoju sądownictwa polegał na spontanicznym ustanawianiu sądów polowych przy dowództwach etapów, większych garnizonów i twierdz. W czasie wojny z Rosja sowiecka w latach 1919-1921 obsługę sąowo-prawną WP na froncie i jego zapleczu zapewniało kilkadziesiąt referatów sądowo-prawnych i sądów polowych związków taktycznych, armii, etapów, twierdz i większych garnizonów² Sądem specjalnym utworzonym dla wyższych dowódców był Sąd Polowy NDWP w Warszawie. Kierownictwo służby sądowo-polowej sprawowało Szefostwo Sądownictwa Polowego usytuowane w pionie Głównego Kwatermistrza NDWP.

Przeszkoda w procesie unifikacji sądownictwa wojskowego w latach wojny z Rosją sowiecką był spadek po zaborcach w postaci trzech odrębnych systemów prawnych. Większość sądów polowych związków operacyjnych, etapów i wielkich jednostek posługiwała się niemieckim prawem karnym wojskowym z 1871 r. dostosowanym do polskich warunków oraz austriacka ustawą wojskowego postępowania karnego z $1912 \mathrm{r}$. W pierwszych miesiącach budowy armii w użyciu był również kodeks wojskowej procedury niemieckiej

${ }^{1}$ Zob. np.: T. Wyszomirski, Pierwsze dni sqdownictwa wojskowego $w$ niepodlegtej Polsce, „Wojskowy Przegląd Prawniczy” 1938, nr 4; J. Krzemieński, Organa wymiaru sprawiedliwości w Wojsku Polskim, „Wojskowy Przegląd Prawniczy” 1928, nr 8-10; A. Kudłaszyk, Wojskowy wymiar sprawiedliwości u progu II RP, „Poglądy i Doświadczenia” 1992, nr 3; L. Kania, Organizacja sqdownictwa wojskowego u progu niepodlegtości Drugiej Rzeczypospolitej (październik 1918 - marzec 1919), w: Księga Pamiatkowa z okazji X-lecia Wydziału Nauk Ekonomicznych i Prawnych Uniwersytetu Przyrodniczo-Humanistycznego $w$ Siedlcach, red. A. Duk-Majewska, D. Strus, Siedlce 2014, s. 124-144; S. Przyjemski, Organizacja wojskowego wymiaru sprawiedliwości w Powstaniu Wielkopolskim, „Wojskowy Przegląd Prawniczy” 1968, nr 4; Organizacja sqdownictwa wojskowego w III Powstaniu Ślaskim, „Wojskowy Przegląd Prawniczy” 1981, nr 2.

2 Zob. L. Kania, Wyroki bez apelacji. Sady polowe $w$ Wojsku Polskim $w$ czasie wojny z Rosja Sowiecka 1919-1921, Zielona Góra 2019. 
z 1898 r. W dywizjach Błękitnej Armii gen. Józefa Hallera w sądach polowych do września 1919 r. stosowano francuskie prawo karne ${ }^{3}$. Dlatego za prawdziwy sukces należy uznać utworzenie jednolitego Korpusu Sądowego z prawników dawnych armii zaborczych, audytorów legionowych, oficerów sądownictwa wojskowego przybyłych z Korpusów Wschodnich, audytorów Błękitnej Armii i zmobilizowanych do wojska prawników cywilnych. Przez szeregi służby sprawiedliwości w sądach polowych, terytorialnych sądach wojskowych, referatach sądowo-prawnych i kierowniczych agendach sądownictwa wojskowego w latach 1919-1921 przewinęło się ok. 940 prawników wojskowych.

Analiza wyroków i dokumentów wytworzonych przez dowództwa i organy wojskowe w latach 1919-1921 potwierdza tezę, że sądy wojenne w trakcie wojen o granice odrodzonej Rzeczypospolitej nie wymierzały sprawiedliwości. Nie były „trzecią siłą” w rozumieniu monteskiuszowskiego modelu trójpodziału władz, lecz pełniły służebną rolę w systemie dowodzenia i utrzymania wewnętrznej spoistości wojska. W pierwszej fazie wojny prawnicy wojskowi odreagowywali kilkuletnią służbę w audytoriatach armii zaborczych. Śledztwa i rozprawy sądowe cechowała nieuzasadniona przewlekłość, a sposób zbierania i weryfikacji materiału dowodowego przypominały działalność sądów wojskowych w okresie pokoju ${ }^{4}$. Kierownictwo służby sprawiedliwości z różnym skutkiem próbowało temu przeciwdziałać i dyscyplinowało oficerów Korpusu Sąowego, a sfrustrowani dowódcy wielkich jednostek powoływali często sądy wojenne ze składu osobowego własnych jednostek. Latem $1920 \mathrm{r}$. krytyczna sytuacja na froncie wymusiła jakościową zmianę podejścia sądów polowych do zadań. NDWP jako dysponent służby sądowo-polowej określiło nowe obowiązki sądów polowych w drodze wprowadzenia trybu postępowania doraźnego i nowej organizacji sądownictwa na przedmościu Warszawy. Nawet w obliczu groźby klęski sądy polowe orzekały najwyższy wymiar kary wyłącznie po udowodnieniu podsądnym winy. Kontrofensywie znad Wieprza i zwycięskim bojom 5 Armii nad Wisła i Wkrą nie towarzyszył huk plutonów egzekucyjnych. W żadnym razie nie stawiam tezy, że Temida wojskowa wpłynęła na wynik tej czy innej operacji w toku wojny. Sądy polowe okazały nikła przydatność w utrzymaniu karności w czasie odwrotu dywizji Frontu Północno-Wschodniego w czerwcu i lipcu 1920 r. Olbrzymie straty, ciagły odwrót i nieustalona linia frontu paraliżowały pracę sądów. Nawet surowe wyroki nie zrobiłyby w tym czasie wrażenia, gdyż żołnierz bardziej obawiał się kozackiego pałasza niż oddania pod sąd polowy. Wielu żołnierzy objętych

\footnotetext{
${ }^{3}$ Zob. T. Szczygieł, Wojskowe postepowanie karne w II Rzeczypospolitej (1918-1939), Katowice 2017; idem, Wojskowe postępowanie polowe $i$ doraźne w II Rzeczypospolitej, „Z Dziejów Prawa" 2016, t. IX (XVII), s. 59-82.

${ }^{4}$ Podobne zachowania sędziów Izby Wojskowej Sądu Najwyższego odnotowano po przemianach polityczno-ustrojowych w $1989 \mathrm{r}$.
} 
śledztwami i dochodzeniami poległo $\mathrm{w}$ walce $\mathrm{z}$ wrogiem. Paradoksalnie sądy polowe nie okazały się też przydatne w czasie ofensywy Grupy Uderzeniowej znad Wieprza i w dniach pościgu za rozbitymi armiami Tuchaczewskiego. Zwycięskich szeregów nie trzeba było bowiem dyscyplinować. Temida wojskowa pokazała natomiast pazur wobec dezerterów i ludzi uchylających się od poboru w przededniu bitwy o Warszawę i Lwów. Zaznaczyła się surowymi wyrokami na odbitych terenach. Salwy plutonów egzekucyjnych spełniły swoją rolę, obwieszczając powrót polskiego państwa i przywracając jego autorytet. Służba sprawiedliwości swoją obecnością spełniła wyznaczona jej rolę. Była jedną $\mathrm{z}$ wielu kostek domina w śmiertelnej grze o przetrwanie narodu i państwa. Prócz nich na polu egzekwowania porządku publicznego i zwalczania dezercji zaznaczyły się „Komisje Sądzące”. Organy te powołano do szybkiego reagowania na zagrożenie karności i porządku prawnego w pasie przyfrontowym głównie na Mazowszu, obszarze Okręgów Generalnych Kielce i Lublin. Komisje składały się z oficera Korpusu Sądowego, oficera żandarmerii i drużyny żandarmów ${ }^{5}$. Prawdopodobnie organy te nazwą nawiązywały do „wojenno-sledstwiennych komisyj” z czasów Królestwa Polskiego jako quasi-organy sądowe, które do $1862 \mathrm{r}$. funkcjonowały w armii rosyjskiej ${ }^{6}$. W czasie Bitwy Warszawskiej dostawiano do nich żołnierzy przychwyconych na dezercji, wałęsaniu się bez przydziału, poszukujących macierzystych jednostek i mężczyzn w wieku poborowym. Po ustaleniu statusu delikwentów przekazywano do stacji zbornych i oddziałów zapasowych bądź pośpiesznie sądzono, niektórych dla przykładu skazywano na śmierć i rozstrzeliwano.

W trakcie wojny z Rosją sowiecką sądy polowe, lotne sądy doraźne i ekspozytury sądów polowych załatwiły kilkadziesiąt tysięcy spraw karnych, z tego ok. 7 tys. wyrokami. W czasie pierwszych dziesięciu miesięcy $1920 \mathrm{r}$. sądy polowe rozwiązały ok. 11 tys. spraw karnych, z czego 3 tys. wyrokami. W sądach polowych zapadło ok. 550 wyroków śmierci, zaś w terytorialnych sądach wojskowych - dalszych 150 wyroków śmierci. W okresie Bitwy Warszawskiej orzeczono co najmniej 270 wyroków śmierci, z których większość została wykonana ${ }^{7}$. Z tej liczby na okres rozliczeń z kolaborantami przypada połowa wyroków śmierci ${ }^{8}$. Zwierzchnicy sądowi zatwierdzali w toku wojny

${ }^{5}$ J. Suliński, Żandarmeria organ bezpieczeństwa armii 1918-1945, Warszawa 2003, s. 98.

${ }^{6}$ „Wojenno-sledstwiennyje komisyje” składały się z 4-7 oficerów i audytora. Funkcjonowały w armii rosyjskiej do 1862 r., kiedy to zostały zastapione przez sądy wojenne. Zob. J. Niemojewski, Podstawy prawne wyroków sqdów wojskowych rosyjskich w powstaniu 1863 roku na terytorium Królestwa Polskiego. Szkic historyczno-prawny, Lublin 1925, s. 11.

7 Wojskowe Biuro Historyczne (dawne Centralne Archiwum Wojskowe w Warszawie-Rembertowie [dalej: CAW]), I.300.10.12, Sprawozdania statystyczne dot. obciążenia sądów terytorialnych i sądów polowych sprawami karnymi, w: Raport szefa Oddziału VI Prawnego Sztabu MSWojsk. do Ministra Spraw Wojskowych z 1.04.1921 r., sygn. L.8313/1882/21.03./ Tajne; T. Rybicki, Sadownictwo polowe w latach wojny 1919-1921, „Wojskowy Przegląd Prawniczy" 1928, nr 8-10, s. 55.

8 J. Krzemieński, op. cit., s. 55. 
średnio co drugi orzeczony wyrok śmierci, co ostatecznie daje nie więcej niż ok. 500 żołnierzy i cywilów rozstrzelanych w tej wojnie na mocy wyroków sądowych. Trzeba pamiętać, że wyroki śmierci orzeczone przez sądy polowe na Ukrainie w 1920 r. zastępowały działalność sądownictwa powszechnego, gdyż dotyczyły prowadzenia działalności antypaństwowej i okrucieństw popełnionych na polskiej ludności i jeńcach wojennych w pierwszej połowie 1919 r. Najwięcej danych statystycznych zachowało się z 1920 r. W tymże roku tylko do terytorialnych sądów wojskowych wpłynęło ogółem 150997 doniesień, zawiadomień, skarg i pism, które wywołały czynności tych sąów. To obrazuje obciążenie prokuratorów sądów wojskowych przy Dowództwach Okręgów Generalnych (DOGen.), które wyniosło 1317 spraw na jednego oficera KS. Sędziowie śledczy wszystkich dziesięciu DOGen. tylko w 1920 r. załatwili 91025 spraw, z których 29386 śledztw lub dochodzeń zakończyli wniesieniem aktów oskarżenia. Statystycznie każdy sędzia śledczy w 1920 r. załatwił 785 spraw karnych. Uzupełnieniem tych danych jest informacja, że w I instancji wszystkie sądy wojskowe przy DOGen. tylko w 1920 r. wydały 7374 wyroki. W toku dwuletniej wojny wyroków mogło być dwukrotnie więcej.

\section{Sądy polowe wobec spektakularnych wydarzeń na froncie}

Akta sądowe i dokumenty wytworzone $\mathrm{w}$ sądownictwie polowym $\mathrm{w}$ latach 1919-1921 zachowały się w stanie szczątkowym. Z archiwaliów, które przetrwały pożogę ostatniej wojny, wynika, że dowództwa wojskowe oczekiwały od sądów polowych rozstrzygnięć przekraczających ich możliwości i zakres działania. Od prawników wojskowych żądano bowiem prawnokarnej oceny błędów popełnionych przez dowódców na polu walki lub ustalenia przyczyn utraty zdolności bojowej swoich oddziałów. Przykładowo rtm. Tadeusz Krynicki czasowo dowodzacy detachmentem, po całkowitym zniszczeniu batalionu kpt. Bolesława Zajączkowskiego pod Zadwórzem 17 VIII 1920 r., złożył wniosek o pociągnięcie do odpowiedzialności za błędy w dowodzeniu dowódcę XI Brygady Piechoty, płk. Karola Szemiota. Sprawą zają się sąd polowy 5 DP, ale mimo licznych ponagleń i zainteresowania śledztwem ze strony NDWP i dowódcy 6 Armii tak długo przeciagał czynności, że sprawa umarła śmiercią naturalną . Analiza podobnych przypadków uprawnia do wniosku, że prawnicy wojskowi nie chcieli się wikłać w procesową ocenę rozkazów podejmowanych przez dowódców na polu walki. I chyba nie taka rola im przypadała. Czym innym było reagowanie na przypadki tchórzostwa, dezercji, podżegania do buntu i odmowy wykonania rozkazu, a czym innym ocena skomplikowanej sytuacji w skali operacyjnej lub taktycznej. $\mathrm{Z}$ reguły każdy szef sądu polowego miał

${ }_{9}$ CAW, I.311.6.19. Zob. też: T. Grzegorczyk, 6. Armia Wojska Polskiego w 1920 r., Toruń 2009, s. 296-298. 
własne doświadczenia z lat 1914-1918, wiedział, czym jest dynamika pola walki i jaką rolę pełni na wojnie łut szczęścia i przypadek. W przeciwieństwie do niego historyk znajduje się po latach w komfortowej sytuacji, gdyż ma możność zajrzeć w karty wszystkim graczom i wysłuchać relacji świadków, w tym animatorów wydarzeń. Te znajdziemy w memuarach, jakich nie brak po każdej wojnie. Badaczowi sprzyja sam upływ czasu, gdyż pozbawia go emocji, które zawsze są wrogiem prawdy. W czasie rzeczywistym prawnik wojskowy takich możliwości nie miał i był poddany ciśnieniu rozkazodawcy. Zwykle nie posiadał fachowej wiedzy wymaganej w dowodzeniu na szczeblu operacyjnym lub wszystkich danych do wypracowania decyzji.

W miarę upływu czasu dowódcy frontów, armii i dywizji nabrali przekonania, że oddawanie sprawy sądom polowym w kwestii oceny jakości dowodzenia nie było dobrym pomysłem. Stąd namnożenie się w drugim roku wojny różnych komisji pod przewodnictwem cenionych generałów i oficerów starszych. W ostatniej fazie wojny takie komisje powoływano na szczeblu armii, zaś w ich skład wchodzili oficerowie sztabowi. Przykładowo w końcu września 1920 r. szef sztabu 3 Armii powołał komisję ds. zbadania zasadności chaotycznego odwrotu grupy mjr. Grabowskiego po walkach z sowiecka 57 DS pod Sławatyczami i Wisznicami 7 i 8 VIII 1920 r. Komisja ta liczyła 4 oficerów, tj. 2 oficerów SGWP w stopniach majorów i 2 kapitanów ${ }^{10}$. W razie stwierdzenia błędów w dowodzeniu i złego rozkazodawstwa materiały z prac komisji były przesyłane sądom polowym. Przed sądami stawiano zatem trudne zadania przeprowadzenia prawnokarnej oceny określonej sytuacji na polu walki. Zwłaszcza wtedy, gdy Naczelny Wódz lub NDWP wysuwali zarzuty wobec konkretnych dowódców. Rzecz w tym, że prawnik wojskowy nie mając odpowiedniej wiedzy, wykształcenia i praktyki dowodzenia oddziałem większym niż pułk piechoty, z konieczności musiał posiłkować się opinią fachowców. Po każdej spektakularnej klęsce na froncie, a nawet po nieuzasadnionym odwrocie z rubieży obronnych Naczelny Wódz, NDWP lub dowódca związku operacyjnego kwestionował sposób dowodzenia i oddawał oficera pod sąd polowy. Ten znów zrzucał z siebie odpowiedzialność i powoływał komisję do oceny konkretnej sytuacji wojennej lub korzystał z opinii komisji, która już działała. Słabością tych komisji było odrywanie dobrych oficerów od dowodzenia i bieżącej aktywności wojskowej. W końcowym etapie wojny przyjęto koncepcję powoływania rzeczoznawcy, który wywodził się z generałów w stanie

${ }^{10}$ CAW, I.311.3.185, Protokół z prac Komisji 3 Armii ds. zbadania paniki w Grupie mjr. Grabowskiego. Z perspektywy lat wydaje się jednak, że bataliony etapowe i wartownicze grupy mjr. Grabowskiego i grupy mjr. Hozera wykonały powierzone im zadanie. Oddziały te stoczyły walki obronne z sowiecka 57 DS na podejściach do Chełma, Lublina i Parczewa, gdzie koncentrowała się Grupa Uderzeniowa dowodzona przez Naczelnego Wodza. Zob. J. Odziemkowski, Użycie batalionów etapowych $i$ wartowniczych wojsk polskich $w$ walkach $w$ Galicji, na Wotyniu i Lubelszczyźnie, 11 lipca - 1 września 1920 roku, „Przegląd Historyczno-Wojskowy" 2014, nr 3, s. 80 i n. 
nieczynnym lub był starszym oficerem NDWP, cieszacym się autorytetem w armii jako operator. Są Wojskowy DOGen. Warszawa wielokrotnie odwoływał się do opinii rzeczoznawców wojskowych w swoich śledztwach. Przykładowo w końcu października 1920 r. sędzia śledczy tłumaczył się z przewlekłości postępowania brakiem opinii rzeczoznawcy w śledztwie przeciwko ppłk. Władysławowi Obuch-Woszczatyńskiemu za samowolne wycofanie się z Łomży i w śledztwie przeciwko ppłk. Juliuszowi Manżettowi za wydanie rozkazu przedwczesnego internowania na Litwie ${ }^{11}$.

Należy odnotować i takie przypadki z tej wojny, że mimo szumnych zapowiedzi i nagłośnienia sprawy nie angażowano sądów przeciw dowódcom, którzy zawiedli w polu. Mimo kompromitujacej postawy 46 pp pod Radzyminem w pierwszych dniach Bitwy Warszawskiej, Zdzisław Musialik, historyk tej wojny, zauważył, że pas obrony 11 DP wynosił $25 \mathrm{~km}^{12}$. Faktycznie miał kilka kilometrów więcej ${ }^{13}$. Natarcia dwóch bojowych dywizji sowieckich i brygady z trzeciej dywizji w wąskim pasie działania mogła nie zdzierżyć nawet jedna z dywizji wielkopolskich, a co dopiero kilkutysięczna uzbrojona formacja sklecona naprędce $z$ dezerterów, ochotników i kryminalistów ${ }^{14}$. Norman Davies autorytatywnie stwierdził, że „w ogniu walk pod Radzyminem 11 Dywizja Piechoty odmówiła wykonywania rozkazów"15. Zarzut poważny, tyle że pochopny i nieprawdziwy. Zawiódł dowódca pułku, ale młodzi oficerowie robili, co mogli. Kilku z nich zresztą poległo. Generał Lucjan Żeligowski wspominał trudny dzień 13 VIII 1920 r. następująco: „Po ciężkich walkach 46-y pułk piechoty z 11 dywizji został odrzucony z pierwszej linji; nieprzyjaciel zajął Radzymin"16. Wielu młodych żołnierzy zbiegło na tyły, ale inni zostali i bili się mężnie. Odosobnione grupy z oficerami zostały w okopach i walczyły na bagnety. Z meldunków wiemy, że 46 pp 13 VIII 1920 r. odparł kilka ataków. Jego trzy kompanie biły się nieźle, a następnego dnia batalion z 46 pp udanie kontratakował, biorac jeńców, karabiny maszynowe i kilka dział. 47 pp walczył ze zmiennym szczęściem pod Leśniakowizna, gdzie odparł kilka ataków nieprzyjaciela. Janusz Odziemkowski jest zdania, że krytyka poczynań 46 pp była usprawiedliwiona, choć nazbyt surowa. Ten wybitny znawca polskiej wojskowości XX w. powtórzył, że na słaby, źle przygotowany

${ }^{11}$ CAW, I.301.21.22, Pismo Sądu Wojskowego DOGen. Warszawa do NDWP z 30.10.1920 r. nr 88/20.

12 Z.M. Musialik, Wojna polsko-bolszewicka 1919-1920, Włocławek 1994, s. 111.

${ }^{13}$ M. Pruszyński, Wojna 1920 roku. Dramat Piłsudskiego, przedmowa J. Pajewski, wyd. 3, Warszawa 1999, s. 192.

${ }_{14}$ Przed bitwą o Warszawę do 46 pp wcielono ok. 700-1000 dezerterów - według różnych źródeł. Pozostali żołnierze byli nieprzeszkolonymi ochotnikami. Zob. Bitwa Warszawska 13-28 VIII 1920. Dokumenty operacyjne. Cz. 2 (17-28 VIII), oprac. M. Tarczyński i in., Warszawa 1996, s. 142.

${ }_{15}$ N. Davies, Orzet biały, czerwona gwiazda. Wojna polsko-bolszewicka 1919-1920, tłum. A. Pawelec, Kraków 2011, s. 236.

${ }^{16}$ L. Żeligowski, Wojna $w$ roku 1920. Wspomnienia i rozważania, Warszawa 2015, s. 95-96. 
i kiepsko dowodzony 46 pp wyszło natarcie trzykrotnie silniejszego przeciwnika w postaci doborowych oddziałów Armii Czerwonej ${ }^{17}$. Kiedy pod Ossowem przejściowo poszły w rozsypkę bataliony $36 \mathrm{pp}$ Legii Akademickiej i $21 \mathrm{pp}$ z 8 DP, nikt tych pułków nie rozwiązywał. Ale też natężenie walk było takie, że w ciagu kilku godzin walk pod Ossowem $\mathrm{z}$ obu stron zginęło więcej żołnierzy niż w czasie tygodniowego szturmu na Monte Cassino. Odium dotknęło nieszczęsny 46 pp, który po rejteradzie dwóch batalionów spod Radzymina gen. Haller rozkazał wykreślić po wsze czasy ze spisu jednostek WP, a nieudolnego dowódcę pułku oddać pod sąd polowy ${ }^{18}$. Generałowie Haller i Tadeusz Rozwadowski nie zdecydowali się pociagnąć do odpowiedzialności karnej dowódcy tego pułku, płk. Bolesława Jaźwińskiego. Ale wniosek o wszczęcie śledztwa utknął w szufladach decydentów wojskowych, kiedy się okazało, że ucieczka z pola walki kilkuset żołnierzy pułku nie była wina jego dowódcy. Mimo nieporadności w dowodzeniu płk. Jaźwińskiego skądinąd wiemy, że 46 pp otrzymał wcześniej uzupełnienia z więzień wojskowych, stacji zbornych dla dezerterów i kilkuset nieostrzelanych ochotników, a na jego odcinek wyszło natarcie dwóch doborowych dywizji sowieckich. Ktoś doszedł wreszcie do wniosku, że wina rozkłada się na wielu ludzi lub przypomniał sobie stara maksymę, że zwycięzców się nie sądzi. W każdym razie płk Jaźwiński przed sądem za to nie stanął.

\section{Sformowanie 1 BPRez. i jej pogrom nad Słuczą i Horyniem}

Idea utworzenia formacji rezerwowych kiełkowała od połowy $1919 \mathrm{r}$. W końcu czerwca tego roku narodził się pomysł utworzenia dodatkowych 65 pułków rezerwowych w ten oto sposób: każdy pułk miał dodatkowo stworzyć batalion zapasowy, który docelowo winien uformować się w nowy pułk. Numeracja pułków rezerwowych była czytelna: numer pułku, który tworzył batalion zapasowy, powiększano o liczbę „100”. Przykładowo jeśli pułk rezerwowy tworzono na bazie batalionu zapasowego $5 \mathrm{pp}$, to oznaczano go jako $105 \mathrm{pp}$. Plan ten okazał się w praktyce zbyt ambitny wobec finansowych możliwości państwa. W końcu 1919 r. został okrojony do kilkunastu dwupułkowych brygad piechoty. W rzeczywistości w drugim roku wojny zdołano utworzyć tylko dwie brygady rezerwowe: 1 BPRez. i 7 BPRez., ale zrezygnowano z dwupułkowej struktury. Idea powołania Armii Rezerwowej ziściła się dopiero w sierpniu 1920 r., gdy Armia Czerwona dotarła na przedpola Warszawy ${ }^{19}$.

\footnotetext{
${ }_{17}$ J. Odziemkowski, Piechota polska w wojnie z Rosja bolszewicka 1919-1920, Warszawa 2010, s. 699.

${ }^{18} \mathrm{Z}$ dniem 1 X 1921 r. 46 pp wykreślono z wykazu pułków WP i przemianowano na 5 Pułk Strzelców Podhalańskich.

19 Zob. J. Kirszak, Armia Rezerwowa gen. Sosnkowskiego w roku 1920, Warszawa 2013.
} 
Po brygadach rezerwowych w NDWP wiele sobie obiecywano. Jako pierwsza powstała 7 BPRez. złożona z żołnierzy ślaskich i wielkopolskich. To była silna liczebnie i ogniowo wielka jednostka piechoty. Zdaniem Odziemkowskiego brygada ta przewyższała liczebnie niektóre dywizje piechoty (94 oficerów, 7100 żołnierzy w stanie bojowym, 187 ckm-ów; stan żywienia - 148 oficerów i 9799 żołnierzy) ${ }^{20}$. Większość żołnierzy poległa lub została wytrącona z linii bojowej w lipcowej bitwie nad Autą bądź w zaciekłych walkach odwrotowych. W czasie Bitwy Warszawskiej pozostało w brygadzie nie więcej niż $20 \%$ żołnierzy z pierwotnego składu. Mimo to 7 BPRez. dzielnie walczyła w bojach o Zegrze, Serock i pędziła rozbite pułki sowieckie do Łomży. Wielkie nadzieje pokładano w drugiej jednostce rezerwowej, tj. w 1 BPRez., która utworzono rozkazem szefa Oddziału I Sztabu MSWojsk. nr L. 6666/Mob. z 27 V 1920 r. Szef Departamentu I Sztabu MSWojsk. rozkazem nr 2000/tj.Piech.I.Mob. powierzył DOGen. Warszawa pełne zabezpieczenie organizacji brygady rezerwowej. Sztab brygady, 101 pp i 105 pp utworzono w Ostrowie Łomżyńskim, natomiast 106 pp w Zambrowie. Kadra podoficerska dla 101 pp i 105 pp pochodziła ze szkół podoficerskich z Mazowsza, natomiast podoficerów dla 106 pp ściagnięto ze Szkoły Podoficerskiej w Biedrusku k. Poznania ${ }^{21}$. Tempo tworzenia nowej formacji było oszałamiające. Z pewnością zaważyła tu groźba odcięcia i zniszczenia na Ukrainie 3 Armii gen. Śmigłego-Rydza. Ten pośpiech miał się szybko srogo zemścić.

Pogotowie marszowe 1 BPRez. określono na 10 VI 1920 r. Na stanowisko dowódcy brygady wyznaczono płk. Krupowicza, który dotąd zajmował się szkoleniem podoficerów w Biedrusku ${ }^{22}$. Brygada rezerwowa była pierwszą z formacji tego typu. W jej skład weszły trzy rezerwowe pułki piechoty: $101 \mathrm{pp}, 105 \mathrm{pp}$ i 106 pp; pułk artylerii i formacje tyłowe. Po wydaniu rozkazu o utworzeniu 1 BPRez. rozwiązano Obóz Szkół Podoficerskich w Ostrowie Łomżyńskim, a batalion nowo wcielonych elewów przeniesiono do Biedruska. W przełomowym okresie wojny zawieszono szkolenie we wszystkich szkołach wojskowych, a podchorążych, elewów i kadrę oficerską tych szkół skierowano na front. Z nielicznej kadry oficerskiej rozwiązanego obozu w Biedrusku utworzono pion dowódczy 101 pp i 105 pp. Materiał żołnierski wszystkich trzech pułków był różnorodny. 101 pp i 105 pp pochodził z kompanii marszowych zebranych z wszystkich DOGen. W części składał się z ozdrowieńców, kryminalistów, żołnierzy ukaranych przez sądy z odroczeniem wykonania kar i dezerterów, przeciwko którym nie zdążono wszczaćc śledztw ze względu na zwyczajny brak

\footnotetext{
20 J. Odziemkowski, Piechota polska..., s. 332.

${ }^{21}$ Ibidem, s. 333.

${ }^{22}$ Według badań Lecha Wyszczelskiego dowódca 1 BPRez. był gen. Paweł Szymański. Zob. L. Wyszczelski, Wojna polsko-rosyjska 1919-1920, t. I, Warszawa 2010, s. 516; idem, Lwów 1920, Warszawa 2014, s. 25-26, choć w kolejnej pracy tego autora Wojsko Polskie w latach 1918-1921, Warszawa 2006, s. 359, gen. Szymański został zlokalizowany jako dowódca $10 \mathrm{BP}$.
} 
czasu $^{23}$. W najgorszej sytuacji był 106 pp, który skompletowano z oficerów administracji, komend uzupełnień, z żołnierzy karanych za dezercje i rekrutów pochodzenia żydowskiego. Wobec tych ostatnich zachodziło podejrzenie, że nie sa „dostatecznie” zmotywowani do walki. Z dowódców pułków piechoty największe doświadczenie bojowe miał ppłk Włodzimierz Raczyński-Maxymowicz, dawny legionista i szef sztabu Grupy Operacyjnej (GO) gen. Leona Berbeckiego. Z miejsca znalazł wspólny język z dawnym dowódca, co nie było w tym czasie bez znaczenia. Kapitan Wiktor Unrug, dowódca 106 pp, miał piękną kartę bojową z powstania wielkopolskiego. Walczył z Niemcami jako dowódca kompanii, ale nie posiadał praktyki bojowej jako dowódca pułku. Podobne doświadczenie bojowe miał kpt. Jan Bratro, który dowodził 101 pp. Walczył na froncie jako dowódca kompanii w 7 pp Leg., więc także nie miał okazji sprawdzić się w polu na wyższym stanowisku dowódczym. Jednym słowem dwaj dowódcy pułków nie dowodzili formacją większą od kompanii, a oficerowie byli rezerwistami i widzieli dotychczas wojnę zza swoich biurek. Na szczęście kadra podoficerska okazała się jednolita, choć materiał żołnierski był przypadkowy i słaby.

Na papierze 1 BPRez. stanowiła silna jednostkę. 101 pp liczył ok. 4600 oficerów, podoficerów i żołnierzy, 105 pp - ok. 3400, a 106 pp - 4000²4. Kadra podoficerska była dobrze wyszkolona, ale brakowało jej bojowego doświadczenia. Kompanie nie były zgrane w batalionach, a bataliony nie ćwiczyły ze sobą w ramach pułku. Dowództwo brygady nie poznało możliwości swoich oficerów, a ci nie znali swoich żołnierzy. Przerzut brygady na front odbył się w dniach od 9 do 14 VI 1920 r. Trzy pułki 1 BPRez. przetransportowano w eszelonach w rejon działania 3 DPLeg. gen. Berbeckiego do węzła komunikacyjnego Połonne. Na bataliony marszowe czekali oficerowie 3 DPLeg. i rozmieścili je wzdłuż brzegów Słuczy na odcinku Lubar-Ostróg-Zwiahel $^{25}$. Brygada została rozrzucona batalionami na odcinku ok. $100 \mathrm{~km}$, przy czym samodzielna grupę bojowa zajął tylko $105 \mathrm{pp}$. A przeciwnik okazał się wymagający, gdyż były nim niezużyte jeszcze w boju dywizje I Armii Konnej i towarzysząca kozakom piechota.

Do 20 VI 1920 r. trzy pułki 1 BPRez. uzupełniały wyposażenie i przechodziły szkolenie. Katastrofa przyszła kilka dni później. Z piechotą sowiecka żołnierze 1 BPRez. radzili sobie jeszcze dobrze. Pod Miropolem 105 pp ppłk. Raczyńskiego-Maxymowicza odparł natarcie sowieckiego 399 pp i wzią jeńców. Tymczasem jazda Budionnego przejechała się wzdłuż i wszerz po batalionach

${ }^{23}$ Sprawozdanie z działalności Centralnej Szkoty Podoficerów Zawodowych Piechoty nr. 1 za rok 1922 z uwzględnieniem lat 1920 i 1921. Praca zbiorowa oficerów C.SZ.P.Z.P. nr. 1, Chełmno 1923, s. 12-13.

24 J. Odziemkowski, Piechota polska..., s. 334.

${ }^{25} \mathrm{~W}$ dokumentach operacyjnych z tej wojny używano nazwy Zwiahel, która obowiązywała do 1793 r. i została zmieniona po ostatnim rozbiorze Rzeczypospolitej. W latach międzywojnia - Nowogród Wołyński. 
101 pp i 106 pp, wywołując totalną panikę. Nad Horyniem bataliony były otaczane i wycinane w pień. Waleczność poznańskiej kadry podoficerskiej na wiele się nie zdała. Żołnierze dezerterowali i poddawali się wrogowi bez walki. W krótkim czasie 101 pp i 106 pp straciły 70-80\% stanów wyjściowych. Kilkuset żołnierzy zbiegło z okopów na sam widok patroli kozackich. W obronie Ostroga zdolnych i chętnych do walki zostało już tylko 300 żołnierzy. Zebrano ich w zbiorczy batalion. Dowódca brygady, płk Krupowicz walczył jak zwykły żołnierz i przedarł się z okrążenia z pomocą ułanów. Zszokowani żołnierze, których między Lubarem a Ostrogiem nie docięli kozacy lub nie wpadli w niewolę, ponieśli wieść o klęsce na tyły. Wyłapywano ich nawet za Łuckiem. Pozostałych przy życiu załadowano do wagonów i odesłano na Mazowsze. W krótkim czasie poległo, zdezerterowało lub poszło w niewolę ok. 6-7 tys. żołnierzy. Pułki 105 i 106 praktycznie przestały istnieć. Żołnierzy, którzy ocaleli ze 105 pp po walkach nad Słucza, wycofano do Lwowa i tam pułk uzupełniono ochotnikami. 105 pp działając w składzie Grupy Taktycznej gen. Pawła Szymańskiego w lipcu 1920 r., walczył potem pod Komarówka. Niestety, pułk nie wytrzymał widoku szarżujących kozaków i poszedł w rozsypkę. Jednego dnia stracił 75\% ludzi i narobił problemów sąsiedniej $18 \mathrm{DP}^{26}$. W lipcu 1920 r. odtworzono i uzupełniono ochotnikami także rezerwowy 101 pp. Pułk ten walczył dzielnie w obronie Modlina, pod Grajewem i Pułtuskiem, a po wojnie został przemianowany na 84 Pułk Strzelców Poleskich ${ }^{27}$.

\section{Śledztwo w sprawie klęski 1 BPRez.}

Pogrom 1 BPRez. na Wołyniu odbił się głośnym echem na szczytach władz wojskowych, albowiem z formacjami rezerwowymi wiązano nadzieje na przywrócenie ciagłości frontu. Na żądanie szefa Oddziału V Sztabu MSWojsk. sąd polowy NDWP w Warszawie wszczą śledztwo - jak to ują prokurator ppłk Witold Szulborski - w sprawie „utraty wartości bojowej 1 BPRez. w walkach na Ukrainie". W praktyce oznaczało to wdrożenie śledztwa przeciwko dowódcom 1 BPRez., tj. płk. Krupowiczowi i szefowi sztabu brygady mjr. Stanisławowi Weckiemu. Większość podobnych śledztw kończyła się szybkim aktem oskarżenia, błyskawicznym wyrokiem i sromotnym końcem karier wojskowych tych oficerów. Dowódcy 1 BPRez. postanowili odrzucić rolę kozłów ofiarnych i twardo się bronić. Nieoczekiwanie zyskali ważnego sojusznika, który podał im rękę. A okazał się nim prokurator sądu polowego NDWP w Warszawie, ppłk Szulborski ${ }^{28}$. Ten doświadczony prawnik szybko wgryzł się w sprawę

${ }^{26}$ F.A. Arciszewski, Ostróg - Dubno - Brody. Walki 18. Dywizji Piechoty z konna armia Budionnego (1 lipca - 6 sierpnia 1920), Oświęcim 2016 (reprint), s. 151.

27 J. Odziemkowski, Piechota polska..., s. 334.

${ }^{28}$ Witold Stefan Szulborski (1885-1967) - w latach 1907-1911 studiował prawo w Kijowie, gdzie działał w polskich korporacjach akademickich i Stowarzyszeniu Przyjaciół Strzelca. 
i doszedł do wniosku, że ktoś „na górze” chce przykryć swoje błędy kosztem dowódców 1 BPRez. Co gorsza, zamierzał to uczynić jego rękami. Mimo braku kompletnych akt śledztwa na szczęście zachowały się dokumenty i protokoły z węzłowych czynności w tej sprawie. Dokumenty te pozwalają wyjaśnić tragiczny los 1 BPRez. i ocenić po latach sposób prowadzenia śledztwa.

W początkowym stadium śledztwa ppłk Szulborski postanowił uczynić zadość świętej dla karnisty zasadzie audiatur et altera pars (,wysłuchaj drugiej strony") i poznać wersję oficerów pomówionych o błędy w dowodzeniu. To było ze wszech miar właściwe i mądre, gdyż oskarżyciel mógł zawczasu poznać linię obrony, która płk Krupowicz i mjr Wecki mogli zaprezentować na rozprawie. Dojście do prawdy na tym etapie śledztwa wstępnego pozwalało uniknąć błędnej decyzji o wniesieniu aktu oskarżenia, ewentualnego wyroku uniewinniającego i narażenia się na niekompetencje lub kompromitację. Prokurator zażądał od kierownictwa Oddziału V Sztabu MSWojsk. raportów, które dowódcy 1 BPRez. złożyli po powrocie z frontu. A o tym, że takie raporty zostały sporządzone, wiedział od płk. Krupowicza. To pozwoliło mu przygotować się do czynności procesowych z udziałem dowódców brygady, zakreślić krag świadków i ustalić, jakie dokumenty musiały znaleźć się $\mathrm{w}$ materiałach śledztwa. $\mathrm{W}$ tym miejscu należy wziąć pod uwagę pozaprocesowe informacje, których nie zlekceważy żaden prokurator i śledczy. Tym źródłem z pewnością byli oficerowie NDWP, wśród których na co dzień obracali się prawnicy wojskowi. Wprawdzie prokurator sam nie prowadzi pracy operacyjnej i nie czerpie wiedzy w ten sposób, niemniej plotki i prywatne opinie sztabowców docierały do sądu polowego NDWP. Generał Stefan Rowecki, w tym czasie oficer Oddziału I Organizacyjnego NDWP, w swoich wspomnieniach nie krył negatywnego stosunku do pomysłu wprowadzania do boju pośpiesznie tworzonych formacji rezerwowych, a pomysł ten zrodził się

Od 1911 do sierpnia 1914 pracował w adwokaturze kijowskiej. W latach 1914-1915 w rosyjskiej 70 Brygadzie Artylerii. Od września 1915 w audytoriacie armii rosyjskiej. Prokurator przy sądzie wojskowym w rosyjskim IX Korpusie Piechoty i zarazem prezes Związku Wojskowych Polaków w Rosji. Od sierpnia 1917 do września 1918 prokurator Sądu Polowego I Korpusu Polskiego gen. J. Dowbora-Muśnickiego i jego doradca prawny. Od listopada 1918 w Warszawie, gdzie współtworzył sądownictwo wojskowe. Od końca 1918 członek Prawniczej Komisji Kwalifikacyjnej weryfikującej i zatwierdzającej audytorów Polaków byłych armii zaborczych do służby w WP. Od końca grudnia 1918 do kwietnia 1919 naczelnik Wydziału Ustaw Sądowych Departamentu II Wojskowo-Prawnego MSWojsk. W 1920 prokurator Sądu Polowego NDWP w Warszawie. Z końcem 1921 podprokurator Najwyższego Sądu Wojskowego. 1925 - sędzia NSW. Od 1929 w stanie spoczynku. W 1929 przyjęty do stołecznej palestry. We wrześniu 1939 na wezwanie władz wojskowych organizator i szef służby sprawiedliwości Dowództwa Obrony Warszawy i szef sądu polowego armii „Warszawa”. W czasie okupacji zastępca szefa służby sprawiedliwości ZWZ-AK. Przewodniczący Wojskowego Sądu Specjalnego przy KG AK, ps. Mora. Przewidywany na szefa Departamentu Sprawiedliwości MON po wojnie. Zmarł w 1967 i został pochowany w Warszawie. 
w Oddziale I Sztabu MSWojsk ${ }^{29}$. Podobnie krytycznych poglądów mogło być więcej. Osobiście przyłączam się do tych badaczy, którzy krytykują „rzucanie na front" całych formacji ochotniczych. Lepsze efekty zyskiwano, rozdzielając materiał z uzupełnień międzyfrontowych wyjadaczy. Bądź co bądź wojny nie były wynalazkiem XX w.

Już pierwsze czynności procesowe i raporty służbowe wprowadziły postępowanie na właściwe tory. Sądzę, że ppłk Szulborski prowadząc formalnie śledztwo w sprawie „utraty wartości bojowej 1 BPRez. na Ukrainie”, w toku weryfikacji linii obrony podejrzanych postawił sobie podstawowe pytanie: czy brygada rezerwowa miała wartość bojowa, wychodząc w pole? Śledztwo wykazało, że od wydania rozkazu o utworzeniu 1 BPRez. do planowanego osiagnięcia zdolności bojowej minęło tylko 14 dni. Brygadę sformowano na bazie kilkunastu kompanii elewów szkół podoficerskich w liczbie po 400 kursantów na pułk. Ten sam w sobie dobry materiał żołnierski, choć nieostrzelany, uzupełniony został batalionami marszowymi, które wystawiły DOGen. Warszawa, Kielce, Łódź i Lublin. Jakość rekruta była niska. Większość żołnierzy 1 BPRez. stanowili dezerterzy, którym państwo dało szansę rehabilitacji, i młodzież żydowska, która na ogół była niechętna służbie wojskowej. W błyskawicznym tempie skompletowano trzy pułki, którym przydzielono oficerów ze szkół wojskowych i służb tyłowych. Większość żołnierzy nie przeszła treningu strzeleckiego, a nawet szkolenia podstawowego. Kilka dni później przyszedł rozkaz do zawagonowania doraźnie skleconych pułków i wysłania ich partiami na Ukrainę. Brygada została wyprawiona na front bez zaplecza gospodarczego, kuchni polowych, lekarzy i pielęgniarek, kompanii saperów, kompanii telegraficznej, a nawet bez karabinów maszynowych i koni dla artylerii. Karabiny maszynowe dostarczono w Szepietówce. Sztab brygady był tylko z nazwy. Zabrakło oficerów do sformowania dowództwa i sztabu brygady. Krupowicz nie miał zastępcy. Możemy raczej mówić o skromnym dowództwie brygady, które zostało wysłane na front ostatnim eszelonem. To miało swoje znaczenie kilka dni później. Przed odprawieniem brygady rezerwowej w pole płk Krupowicz raportował gen. Mikołajowi Osińskiemu ${ }^{30}$ i ppłk. Michałowi Tokarzewskiemu ${ }^{31}$ o złym wrażeniu, jaki zrobił na nim przegląd pułków. Odwrotu jednak nie było, gdyż front nad Słuczą dosłownie trzeszczał w szwach.

Po dotarciu do Szepietówki 19 VI 1920 r. płk Krupowicz i mjr Wecki zastali nietypową sytuację. Na dowództwo 1 BPRez. czekał kpt. Trapszo, szef sztabu 3 DPLeg., który poinformował płk. Krupowicza, że brygada czasowo weszła

${ }^{29}$ CAW, I.301.22.5, Raport dowódcy 1 BPRez. płk. Wacława Krupowicza i szefa sztabu, mjr Stanisława Weckiego, do Dowódcy Frontu Ukraińskiego nr L.153 z 5.07.1920 r. (odpis).

${ }^{30}$ Generał ppor. Mikołaj Osiński pełnił w tym czasie funkcję Generalnego Inspektora Piechoty.

${ }^{31}$ Pułkownik Michał Tokarzewski pełnił w tym czasie funkcję szefa Oddziału Piechoty w I Departamencie Sztabu MSWojsk. 
pod rozkazy gen. Berbeckiego, dowódcy 3 DPLeg. Ze względu na krytyczną sytuację na froncie rezerwowe $106 \mathrm{pp}$ i $101 \mathrm{pp}$ zostały rozproszone batalionami na odcinku frontu długości ponad $100 \mathrm{~km}$ między Zwiahlem a Lubarem, zaś 105 pp stanowił samodzielna grupę bojowa pod Mikropolem. Dowództwo brygady oddano do dyspozycji gen. Berbeckiego, który wedle słów kpt. Trapszy miał przekazać dowodzenie płk. Krupowiczowi po odparciu sowieckiej ofensywy i uspokojeniu sytuacji na froncie. Dowództwu 1 BPRez. polecono udać się na prawe skrzydło ugrupowania bojowego nowo utworzonej Grupy Operacyjnej „Słucz” do Połonnego, gdzie stacjonował sztab 105 pp.

Podczas śledztwa potwierdzono wersję mjr. Weckiego, że do końca walk nad Słuczą i Horyniem, które zakończyły się rozbiciem brygady, nie mógł rozwinąć środków łączności między pułkami i batalionami. Znaczne odległości między grupami batalionowymi i odsunięcie płk. Krupowicza od dowodzenia pozbawiło podejrzanych wpływu na przebieg walk z konnica Budionnego. W praktyce płk Krupowicz i mjr Wecki nie mogli wpłynać na bieg zdarzeń, gdyż zostali czasowo zwolnieni z pełnionych funkcji. Krupowicz starał się służyć radami w okrążonym Ostrogu, gdzie walczył z wrogiem jak zwykły żołnierz. Z kolei mjr Wecki walczył jako oficer liniowy pod Mikropolem. Prowadzacy śledztwo zorientował się, że ma do czynienia z kuriozalną sytuacja: płk. Krupowicza i mjr. Weckiego pozbawiono dowodzenia, a sąd polowy NDWP miał wobec nich wyciagnąc surowe konsekwencje za błędy popełnione w dowodzeniu (!). To mogło zirytować każdego prawnika.

W śledztwie jednym z podstawowych badanych wątków była ocena zdolności bojowej brygady przed wejściem do walki. Ocena ta wypadła ujemnie. Z przesłuchań świadków, w tym obu dowódców brygady, wyłonił się tragiczny obraz. Karabiny maszynowe rozdzielono na kompanie dopiero w Szepietówce. Niektóre nie nadawały się do walki. Były wysłużone wielomiesięcznym szkoleniem i często się zacinały. W boju jedynie 105 pp radził sobie dobrze, gdyż odparł dwa natarcia sowieckiej 133 BS. Wziął nawet jeńców, w tym dowódcę sowieckiego $399 \mathrm{pp}$. Wobec przerwania frontu pod Zwiahlem przez konnicę Budionnego pułk musiał odejść na Korzec, a potem na Horyń, tocząc walki ze zmiennym szczęściem. W tym czasie dopełniał się los 101 pp i 106 pp, którym gen. Berbecki powierzył długi odcinek frontu od Emilczyna do Zwiahla. Wobec braku koni pułki nie miały wsparcia ze strony artylerii. Na domiar złego na każdą kompanię przypadały tylko dwa karabiny maszynowe. Wszystkie trzy pułki 1 BPRez. cierpiały na brak oficerów. W wyniku pośpiechu wyruszyły na front z połowa kadry. Ciężar dowodzenia musiał spocząc na barkach kaprali. Każdy pułk miał po 66 podoficerów z Wielkopolski i to był materiał żołnierski, na który mogli liczyć dowódcy. W 106 pp znaczny procent stanowili żołnierze pochodzenia żydowskiego. Ci nie przejawiali ochoty do walki. Przy pierwszej akcji bojowej pod Zwiahlem dwa bataliony poszły w rozsypkę. Przez następny dzień wyłapywali ich ułani z 5 pu i żandarmi, po czym bijąc i strasząc, zawracali do okopów. Nie można było postawić ich przed sądem 
polowym, gdyż zabrakło na to czasu i nie sposób było rozstrzelać kilkuset ludzi. Z konnicą Budionnego walczyli głównie oficerowie i elewi, stąd straty bezpowrotne w kadrze dowódczej były olbrzymie. W ciagu pierwszych dwóch dni walk pod Zwiahlem tylko w 106 pp zginęło 20 oficerów i 45 podoficerów. Kaprale z rozpaczy strzelali w twarz każdemu, kto nie chciał walczyć lub bili opornych wyciorami. Wszystko na próżno. Generalnie żołnierze pochodzenia żydowskiego nie chcieli walczyć z Armią Czerwona. Masowo zbiegali do bolszewików, dezerterowali na tyły, chowali się w okopach i porzucali broń. Dowództwo GO „Słucz” zrazu nie wierzyło meldunkom o tragicznym stanie karności w 1 BPRez. Wkrótce musiało uwierzyć, że to prawda. Wypróbowani kaprale z 3 DPLeg. przebrali się w sowieckie mundury i podeszli pod okopy zajmowane przez 106 pp. Tam wyszła do nich grupa żołnierzy Żydów, która wzięła ich za bolszewików i zgłosiła chęć służby w Armii Czerwonej. Klucząc $\mathrm{w}$ terenie, kaprale doprowadzili dezerterów do polskich pozycji, gdzie winowajców aresztowano i oddano pod sąd polowy 3 DPLeg. Dwóch skazano na karę śmierci i wyrok wykonano. Pozostałym wymierzono kary długoletniego ciężkiego więzienia. Ale i to nie przywróciło zdolności bojowej pułku. Rezerwowy $106 \mathrm{pp}$ ostatecznie rozsypał się podczas walk pod Ostrogiem ${ }^{32}$. Ocalałych zbierano w stepie i odsyłano do Ostrowa Łomżyńskiego. To było zadaniem kpt. Roweckiego, oficera Oddziału I Organizacyjnego NDWP, który tak wspominał smutny koniec brygady: „Jako szef sekcji oddziału I sztabu Naczelnego Dowództwa WP zostałem wysłany na Ukrainę dla uporządkowania i zreorganizowania rozbitej 1 brygady rezerwowej, nieudanego zreszta dziecięcia generała Tokarzewskiego. Brygada ta, zlepiona ad hoc z różnych szkół wojskowych, rozleciała się w pierwszych walkach z wyjątkiem pułku pułkownika Rokity-Maksymowicza. W szalonym tempie, pędząc autem po Ukrainie i Wołyniu, pozbierałem resztki niesławnej brygady, zawagonowałem je i odesłałem na reorganizację w głą kraju" 3 .

Ironia przyszłego komendanta głównego AK jest wyraźna. Czytelnika jednak bardziej interesuja przyczyny pośpiesznego klecenia i rzucania na front całych formacji rezerwowych. W armii lądowej USA okres szkolenia i zgrywania elementów dywizji przed wyjściem na front w obu wojnach światowych nie mógł być krótszy niż 18 miesięcy. Ktoś powie, że tak wielki kraj stać było na taki luksus. Poza skrawkami swego terytorium na Pacyfiku nigdy nie został najechany przez nieprzyjaciela. Ale Wehrmacht nawet w krytycznych latach 1944-1945 nie wypuszczał żołnierzy na front wcześniej niż po rocznym szkoleniu. Formacje Volkssturmu zawsze walczyły u boku elitarnych oddziałów Waffen-SS i Wehrmachtu, a przecież składały się

${ }^{32}$ CAW, I.301.22.5, Raport uzupełniajacy szefa sztabu 1 BPRez. mjr. Stanisława Weckiego do Dowódcy Frontu Ukraińskiego nr L.157 z 10.07.1920 r.

${ }^{33}$ S. Rowecki, Wspomnienia i notatki autobiograficzne (1906-1939), wstęp i oprac. A.K. Kunert, J. Szyrmer, Warszawa 1988, s. 88. 
z weteranów I wojny światowej. W latach 1919-1921 w szeregi walczących stron przymusowo wcielano materiał ludzki coraz gorszej jakości. Jakkolwiek źle wybrzmiały te słowa, przywódcy walczących stron mówili o tym otwartym tekstem. Po wielomilionowych stratach młodzieży w latach 1914-1918 i ogołoceniu z wartościowego rekruta z Europy Środkowo-Wschodniej, w rezerwie została wielka rzesza schorowanej, niedożywionej i niewyrośniętej młodzieży. W punktach werbunkowych na terenie Galicji Wschodniej wisiał sznurek na wysokości $150 \mathrm{~cm}$, żeby z miejsca eliminować rekrutów niskiego wzrostu ${ }^{34}$. Inna sprawa, że losy pośpiesznie skleconej i rzuconej na front 1 BPRez. nie mogły być inne. W połowie czerwca 1920 r. sytuacja polskich wojsk na południowy zachód od Żytomierza była krytyczna. 3 Armia gen. Rydza-Śmigłego w ostatniej chwili wyrwała się z kleszczy wroga i próbowała odtworzyć linię frontu. I Armia Konna Budionnego w kilku miejscach rozerwała front, a wybite w obronie dziury Naczelny Wódz starał się zamknąć dywizjami ściagniętymi z północy lub z głębi kraju. Stąd niespodziewana obecność w rejonie Korostenia, Szepietówki i Zwiahla 3 DPLeg., 6 DP i 1 BPRez., które pośpiesznie przerzucono na południe koleja. W pośpiechu odtwarzano 2 Armię gen. Raszewskiego i utworzono GO „Słucz” gen. Jana Romera. Tej ostatniej wyznaczono zadanie powstrzymania i zniszczenia I Armii Konnej na południowy zachód od Żytomierza ${ }^{35}$. Dodajmy, zadanie zupełnie niewykonalne.

Znawcy tej wojny dość zgodnie milczą o tej tragedii, gdyż prawda zawsze jest trudna. Jeśli w tej sprawie należało uruchomić sąd polowy, to na ławie oskarżonych powinien zasiaść raczej oficer, który podją decyzję o rzuceniu niegotowej 1 BPRez. przeciw sowieckiej konnicy. W żadnej armii europejskiej nie wysyłano na front sformowanych w kilka dni wielkich jednostek piechoty. Znamy przypadki zagęszczania rubieży obronnych sowieckiego Frontu Zachodniego pod Moskwą w końcu 1941 r. słabo uzbrojonymi i niewyszkolonymi formacjami robotników, ale to skończyło się okropną rzezią. Znacznie lepsze efekty osiagano w stosowaniu znanego od wieków sposobu uzupełniania strat bezpowrotnych systemem wprowadzania młodego rekruta w miejsce rannego lub zabitego żołnierza. Doświadczenia wyniesione z tej wojny wykazały, że nasycenie oddziału na froncie świeżym rekrutem powyżej $30 \%$ stanu osobowego redukowało w połowie wartość bojową oddziału. Uratował się tylko 105 pp, który najpierw działał zwarcie nad Słuczą i Horyniem, a później został mądrze rozdzielony między bataliony 3 DPLeg.

Obiektywne przedstawienie wojennych losów 1 BPRez. nad Słuczą i Horyniem w czerwcu 1920 r. zawdzięczamy profesjonalizmowi, odwadze i etycznej

\footnotetext{
${ }^{34}$ M. Baczkowski, Pod czarno-żóttymi sztandarami. Galicja i jej mieszkańcy wobec austro-węgierskich struktur militarnych 1868-1914, Kraków 2003, s. 132; L. Kania, W cieniu Orlat Lwowskich. Polskie sqdy wojskowe, kontrwywiad $i$ stużby policyjne w bitwie o Lwów 1918-1919, Zielona Góra 2009, s. 56-59.

${ }^{35}$ L. Wyszczelski, Lwów 1920, Warszawa 2017, s. 24-26.
} 
postawie stołecznego prawnika wojskowego ppłk. Szulborskiego. Oficer ten pełniąc niewdzięczną rolę prokuratora, sporządził odważny raport dla Naczelnego Wodza, przedstawiając fakty bez retuszu. Raport zakończył wnioskiem o umorzenie śledztwa ze względu na brak winy w działaniu płk. Krupowicza i mjr. Weckiego. Zdaniem prokuratora podejrzani nie mieli żadnego wpływu na przebieg walk 1 BPRez., albowiem z momentem przyjazdu na front zostali odsunięci od dowodzenia rozkazem gen. Berbeckiego, dowódcy GO „Słucz”. Naczelny Wódz szczegółowo zapoznał się z aktami śledztwa i pod raportem ppłk. Szulborskiego skreślił znamienne zdanie: „Motywacja nie trafia mi do przekonania, lecz mimo to zarządzam zaniechać dalszych kroków sądowo-prawnych przeciw płk. Krupowiczowi i mjr. Weckiemu. 24/XI/20 - J. Piłsudski”36.

Katastrofa 1 BPRez. i śledztwo bynajmniej nie zaszkodziły oficerom dowództwa brygady w dalszej karierze wojskowej. Pułkownik Krupowicz po wojnie od razu powrócił na stanowiska dowódcze w szkolnictwie wojskowym. W latach dwudziestych został komendantem Placu w Poznaniu i odszedł w stan spoczynku z należnymi honorami. Dowódca 105 pp ppłk Raczyński-Maxymowicz $\mathrm{w}$ latach międzywojnia systematycznie piął się $\mathrm{w}$ górę w hierarchii wojskowej, aż doszedł do stanowiska dowódcy Okręgu Korpusu Nr VIII w Toruniu i lampasów generalskich. Major Wecki po wojnie przez wiele lat dowodził $10 \mathrm{pp}$ w Łowiczu, zaś kpt. Bratro po dramatycznych walkach brygady rezerwowej nad Słucza otrzymał awans do stopnia majora. We wrześniu 1939 r. ppłk Bratro dowodził 29 BP walcząca w składzie armii „Prusy” i Frontu Północnego. Z kolei pechowy dowódca 106 pp kpt. Unrug w tej wojnie zdazżył zasłużyć jeszcze na Krzyż Walecznych za dzielność na polu chwały. Po wojnie otrzymał dowództwo 57 pp i dowodził nim do $1930 \mathrm{r}$. Widzimy, że dowódcy, oficerowie i kadra podoficerska 1 BPRez. nie były przypadkowe. Zdecydowana większość oficerów i podoficerów 1 BPRez. poległa na polu chwały, walcząc nad Słuczą i Horyniem bez wsparcia swoich żołnierzy. Ale ich śmierć nie była daremna. Dywizje I Armii Konnej i 12 Armii szczodrze płaciły krwią za każdą piędź zdobytego Wołynia i nie zdążyły na czas dojść do Lwowa.

\section{Zakończenie}

Po katastrofie 1 BPRez. nad Słuczą na szczytach władz wojskowych zrodziła się myśl usunięcia z szeregów wojska żołnierzy pochodzenia żydowskiego. Żądali tego sami żołnierze, którzy w boju nie mogli liczyć na żydowskich kolegów. Atmosfera wobec żołnierzy Żydów pogarszała się z każdym miesiącem wojny. Napływające z zaplecza frontu informacje o wiarołomstwie

${ }^{36}$ CAW, I.301.22.5, Referat Prokuratora Sądu Polowego ND WP w Warszawie, ppłk. KS Witolda Szulborskiego, sygn. K.49/20/Tjn. z 3.09.1920 r. 
Żydów, współdziałaniu środowisk żydowskich z nieprzyjacielem i masowe dezercje Żydów z jednostek frontowych skłoniły polskie dowództwo do podjęcia radykalnych decyzji. W lipcu $1920 \mathrm{r}$. minister spraw wewnętrznych rozwiązał żydowski Bund i nakazał zamknięcie jego lokalnych siedzib ${ }^{37}$. Następny krok był bardziej drastyczny i spotkał się z krytyką wpływowych środowisk żydowskich w USA i Europie Zachodniej. Rozkazem ministra spraw wojskowych gen. Kazimierza Sosnkowskiego w połowie sierpnia 1920 r. utworzono obóz koncentracyjny dla żołnierzy pochodzenia żydowskiego w Jabłonnie pod Warszawa. Internowanie jako sposób prewencyjnego zabezpieczenia porządku publicznego było w tym czasie częstym sposobem działania organów bezpieczeństwa. Przykładowo w przededniu Bitwy Warszawskiej ze stolicy usunięto wszystkich Rosjan, których prewencyjnie internowano. Instytucję internowania, tj. izolowania osoby podejrzanej bez postawienia zarzutów karnych, przejęto od naszych zaborców i z powodzeniem szeroko stosowano w czasie wojny polsko-ukraińskiej. Od 16 sierpnia do 10 września przez obóz w Jabłonnie przewinęło się od 1,2-1,5 tys. żołnierzy pochodzenia żydowskiego. Niektórzy badacze (Szymon Rudnicki) lub historycy związani z Muzeum Historii Żydów Polskich szacuja liczbę internowanych na 10-17 tys. oficerów i żołnierzy ${ }^{38}$. To kalkulacje przesadne i nieznajdujące oparcia w faktach, ponieważ obóz wojskowy w Jabłonnie logistycznie nie był przygotowany na przyjęcie połowy tej masy ludzi. Obóz nie miał nawet ogrodzenia. Fotografie i relacje żołnierzy Żydów z trzytygodniowego pobytu w Jabłonnie w żadnej mierze nie budza skojarzeń z warunkami więziennymi lub realiami obozu koncentracyjnego. Dla żołnierzy Żydów wydzielono tylko kilka baraków. Nie można również mówić o masowych aresztowaniach żołnierzy pochodzenia żydowskiego. Zwłaszcza o aresztach oficerów (Jolanta Załęczny) ${ }^{39}$. Nikt z tych żołnierzy nie usłyszał zarzutu karalnego przygotowania do dezercji lub odmowy wykonania rozkazu. W zachowanych dokumentach sądownictwa polowego i rozkazach NDWP nie ma o tym śladu. Izolacja i szykany dotknęły przejściowo głównie rekrutów. Możemy mówić o liczbie ok. 1,5 tys. żołnierzy wydalonych z szeregów wojska w związku z histerią antyżydowska, która na kilka tygodni owładnęła armię. W połowie września 1920 r. opróżniono obóz $\mathrm{w}$ Jabłonnie z żołnierzy pochodzenia żydowskiego i zaprzestano stosowania dalszych szykan ${ }^{40}$.

37 J. Szczepański, Wojna 1920 na Mazowszu i Podlasiu, Warszawa-Pułtusk 1995, s. 106.

${ }^{38}$ S. Rudnicki, Żydzi w parlamencie II Rzeczypospolitej, Warszawa 2004, s. 50.

39 J. Załęczny, Wydarzenia wojny polsko-bolszewickiej 1920 roku na terenie ówczesnego powiatu warszawskiego, „Niepodległość i Pamięć” 2010, nr 32, s. 27-28.

${ }^{40}$ Wkład żołnierzy pochodzenia żydowskiego w zwycięstwo nad Rosją sowiecką wymaga osobnych studiów, gdyż jest przedmiotem krańcowych opinii. Alicja Gontarek zbadała narodowość uprawnionych po wojnie do zasiłków z tytułu śmierci żołnierza będącego jedynym żywicielem rodziny w Mińsku Mazowieckim. Na ogółem 61 osób uprawnionych figurowało w dokumentach 16 Żydów. Innymi słowy, na 61 zabitych i zmarłych w czasie wojny żołnierzy WP aż 16 było Żydami. To czyni odsetek $25 \%$ strat bezpowrotnych, podczas 
Po katastrofie nad Słuczą i Horyniem nie poniósł konsekwencji służbowych żaden z dowódców wyższego szczebla, którzy lekką ręką rzucili przeciw konnicy Budionnego niegotowe do walki i naprędce sklecone pułki 1 BPRez. I jak to bywa na wojnie, szybko zapomniano o tej klęsce. Uznano, że tragiczny los brygady był wynikiem braku wojennego szczęścia i splotu niekorzystnych okoliczności, co tylko w części pokrywało się z prawdą. Inaczej należałoby poszukać winnych wśród siebie.

\section{Streszczenie}

Po fiasku wyprawy na Kijów w pasie obrony Frontu Ukraińskiego w pierwszej dekadzie czerwca 1920 r. wytworzyła się niezwykle groźna sytuacja. 3 Armia w ostatniej chwili uniknęła okrążenia i zniszczenia przez oddziały sowieckiego Frontu Południowo-Zachodniego. Dywizje i grupy szybkie I Armii Konnej kontynuowały ofensywę na zachód. Po dotkliwych stratach poniesionych przez oddziały polskie w czasie odwrotu z Kijowa wojska Frontu Ukraińskiego wymagały pilnego wzmocnienia. W tym celu sformowano naprędce z jednostek tyłowych trzypułkową 1 Brygadę Piechoty Rezerwy, którą w drugiej połowie czerwca przerzucono partiami na front na Wołyniu. Tam pułki 1 BPRez. zostały rozrzucone nad Słuczą i oddane pod dowództwo 3 DPLeg. gen. Leona Berbeckiego. W ciagu następnych kilku dni rezerwowe 101 pp i 106 pp zostały całkowicie rozbite, przy czym ten ostatni utracił zdolność bojowa w wyniku masowych dezercji żołnierzy pochodzenia żydowskiego. W sprawie niespodziewanej klęski 1 BPRez. prokurator Sądu Polowego NDWP w Warszawie wszczął śledztwo, które umorzył z uzasadnieniem, że dowódcy brygady nie mieli żadnego wpływu na jej użycie na Wołyniu. Naczelny Wódz Józef Piłsudski zgodził się z poglądem prokuratora i decyzję o umorzeniu śledztwa jako zwierzchnik sądowy zatwierdził. Konsekwencjami klęski 1 BPRez. były wzrost nastrojów antyżydowskich w kierowniczych gremiach sił zbrojnych i utworzenie na krótki czas w sierpniu 1920 r. obozu koncentracyjnego w Jabłonnie dla żołnierzy Żydów.

\section{The Defeat of the First Reserve Infantry Brigade in Volhynia in June 1920 in the Materials of the Prosecutor's Investigation}

After the fiasco of the Kiev expedition in the defence belt of the Ukrainian Front in the first decade of June 1920, an extremely dangerous situation arose. The 3rd Army avoided encirclement and destruction by the troops of the Soviet Southwest Front at the last minute. Divisions and quick groups of the 1st Cavalry Army continued their western offensive. After severe losses suffered by Polish troops during the retreat from Kiev, the Ukrainian Front forces urgently needed to be strengthened. To this end, the three-regiment 1st Reserve Infantry Brigade (1st RIBde) was quickly formed from the rear units, which in the second half of June was moved in parts to the front in Volhynia. There, the three regiments of the 1st RIBde were scattered on the Słucza River and placed under the command of the 3rd Legions Infantry Division Gen. Leon Berbecki. Over the next few days, the reserve 101st and 106th Infantry Regiments were completely broken, with the latter losing combat capability

gdy cała społeczność żydowska w Rzeczypospolitej wynosiła nie więcej niż 10\% obywateli. Stosunek mniejszości żydowskiej do żywiołu polskiego jest więc bardziej złożony, niż to się na ogól wydaje. Zob. A. Gontarek, Żydzi Mińska Mazowieckiego w latach 1918-1939, Lublin 2015, s. 428-432. 
as a result of mass desertions of Jewish soldiers. In the case of an unexpected defeat of the 1st RIBde the prosecutor of the Field Court of the High Command of the Polish Army in Warsaw initiated an investigation, which he discontinued with the justification that the brigade commanders had no influence on its use in Volhynia. Supreme Commander Józef Piłsudski agreed with the prosecutor's view and approved the decision to discontinue the investigation. In consequence of the failure of the 1st RIBde there was an increase anti-Jewish sentiment in commanding circles of the armed forces and the creation of the Jabłonna concentration camp for Jewish soldiers for a short time in August 1920.

\section{Bibliografia}

Arciszewski F.A., Ostróg - Dubno - Brody. Walki 18. Dywizji Piechoty z konna armia Budionnego (1 lipca - 6 sierpnia 1920), Oświęcim 2016 (reprint).

Baczkowski M., Pod czarno-żóttymi sztandarami. Galicja i jej mieszkańcy wobec austro-weggierskich struktur militarnych 1868-1914, Kraków 2003.

Davies N., Orzet biaty, czerwona gwiazda. Wojna polsko-bolszewicka 1919-1920, tłum. A. Pawelec, Kraków 2011.

Gontarek A., Żydzi Mińska Mazowieckiego w latach 1918-1939, Lublin 2015.

Grzegorczyk T., 6. Armia Wojska Polskiego w 1920 r., Torun 2009.

Kania L., Organizacja sqdownictwa wojskowego u progu niepodległości Drugiej Rzeczypospolitej (październik 1918 - marzec 1919), w: Księga Pamiatkowa z okazji X-lecia Wydziału Nauk Ekonomicznych i Prawnych Uniwersytetu Przyrodniczo-Humanistycznego $w$ Siedlcach, red. A. Duk-Majewska, D. Strus, Siedlce 2014, s. 124-144.

Kania L., W cieniu Orlat Lwowskich. Polskie sqdy wojskowe, kontrwywiad i stużby policyjne $w$ bitwie o Lwów 1918-1919, Zielona Góra 2009.

Kania L., Wyroki bez apelacji. Sady polowe w Wojsku Polskim w czasie wojny z Rosja Sowiecka 1919-1921, Zielona Góra 2019.

Kirszak J., Armia Rezerwowa gen. Sosnkowskiego w roku 1920, Warszawa 2013.

Krzemieński J., Organa wymiaru sprawiedliwości w Wojsku Polskim, „Wojskowy Przegląd Prawniczy" 1928, nr 8-10.

Kudłaszyk A., Wojskowy wymiar sprawiedliwości u progu II RP, „Poglądy i Doświadczenia” 1992, nr 3.

Musialik Z.M., Wojna polsko-bolszewicka 1919-1920, Włocławek 1994.

Niemojewski J., Podstawy prawne wyroków sqdów wojskowych rosyjskich w powstaniu 1863 roku na terytorium Królestwa Polskiego. Szkic historyczno-prawny, Lublin 1925.

Odziemkowski J., Piechota polska w wojnie z Rosja bolszewicka 1919-1920, Warszawa 2010.

Odziemkowski J., Użycie batalionów etapowych $i$ wartowniczych wojsk polskich $w$ walkach $w$ Galicji, na Wotyniu i Lubelszczyźnie, 11 lipca - 1 września 1920 roku, „Przegląd Historyczno-Wojskowy" 2014, nr 3.

Organizacja sqdownictwa wojskowego w III Powstaniu Ślaskim, „Wojskowy Przegląd Prawniczy" 1981, nr 2.

Pruszyński M., Wojna 1920 roku. Dramat Piłsudskiego, przedmowa J. Pajewski, wyd. 3, Warszawa 1999.

Przyjemski S., Organizacja wojskowego wymiaru sprawiedliwości w Powstaniu Wielkopolskim, „Wojskowy Przegląd Prawniczy” 1968, nr 4.

Rudnicki S., Żydzi w parlamencie II Rzeczypospolitej, Warszawa 2004.

Rybicki T., Sadownictwo polowe w latach wojny 1919-1921, „Wojskowy Przegląd Prawniczy” 1928, nr 8-10.

Suliński J., Żandarmeria organ bezpieczeństwa armii 1918-1945, Warszawa 2003.

Szczepański J., Wojna 1920 na Mazowszu i Podlasiu, Warszawa-Pułtusk 1995. 
Szczygieł T., Wojskowe postepowanie karne w II Rzeczypospolitej (1918-1939), Katowice 2017. Szczygieł T., Wojskowe postępowanie polowe i doraźne w II Rzeczypospolitej, „Z Dziejów Prawa” 2016, t. IX (XVII).

Wyszczelski L., Lwów 1920, Warszawa 2014, Warszawa 2017.

Wyszczelski L., Wojna polsko-rosyjska 1919-1920, t. I-II, Warszawa 2010.

Wyszczelski L., Wojsko Polskie w latach 1918-1921, Warszawa 2006.

Wyszomirski L., Pierwsze dni sadownictwa wojskowego w niepodlegtej Polsce, „Wojskowy Przegląd Prawniczy” 1938, nr 4.

Załęczny J., Wydarzenia wojny polsko-bolszewickiej 1920 roku na terenie ówczesnego powiatu warszawskiego, „Niepodległość i Pamięć” 2010, nr 32.

Biogr a m: Leszek Kania - dr hab. prof. nadzw. Uniwersytetu Zielonogórskiego. Historyk prawa i wojskowości. Najważniejsze prace: Od Orlą Lwowskich do Ostrej Bramy. Szkice $z$ dziejów wojskowego wymiaru sprawiedliwości i postuszeństwa rozkazowi w dawnym Wojsku Polskim (Sulechów 2008); W cieniu Orlat Lwowskich. Polskie sqdy wojskowe, kontrwywiad i stużby policyjne w bitwie o Lwów 1918-1919 (Zielona Góra 2009); Wilno 1944 (Warszawa 2013); Stużba sprawiedliwości w Wojsku Polskim 1795-1945. Organizacja - Prawo - Ludzie (Siedlce 2015); A. Sobieralski, Ze Śniatyna do Londynu. Wspomnienia wojenne kresowego policjanta (wstęp i oprac.; Siedlce 2016); Wyroki bez apelacji. Sady polowe w Wojsku Polskim $w$ czasie wojny $z$ Rosja Sowiecka 1919-1921 (Zielona Góra 2019). W 2015 r. odznaczony medalem „Pro Memoria” za upamiętnianie sylwetek sądowników AK, NSZ i WiN. E-mail: l.kania.uz@interia.pl. 